\title{
Reviewing the Strategies of Dealing with Corruption in the Europe Union Countries with Regulatory System of the Group of States against Corruption (GRECO)
}

\author{
Behzad Razavi Fard ${ }^{1} \&$ Hamidreza Hassanpour ${ }^{2}$ \\ ${ }^{1}$ Faculty Member of Allameh Tabatabai University, Iran \\ ${ }^{2} \mathrm{PhD}$ Student in International Law at Allameh Tabatabai University, Iran \\ Correspondence: Behzad Razavi Fard, Faculty Member of Allameh Tabatabai University, Iran.
}

Received: April 11, 2016 Accepted: June 15, 2016 Online Published: June 29, 2016

doi:10.5539/jpl.v9n5p47 URL: http://dx.doi.org/10.5539/jpl.v9n5p47

\begin{abstract}
This paper attempts to examine the provisions of the Convention on Combating Bribery of Foreign Public Officials in International Business Contracts, Europe Union Convention on Combating Corruption and also the analysis of the actions of the Council of Europe in implementation of the convention on criminal law, Additional Protocol to the Criminal Law Convention on Corruption and the Convention relating to anti-corruption civil law, in order to describes different ways to combat corruption and provide a suitable solution to combat corruption in the country.

Reviewing the standards and regulations in EU in the executive and legislative sector and inspection system and the Member States known as GRECO, it is concluded that the EU has been trying to implement effective measures by increasing the thematic range and personal inclusion of provisions to combat corruption and strengthen the regulatory system of GRECO; and the success of the EU in this field is largely due to these actions so that it is known as the leader in the fight against corruption according to reports and statistics compiled by Transparency International Organization.

The Europe Union has achieved such success considering appropriate social fields among member states and national and international regulatory systems. Accordingly, generalization of EU pattern to other regional or global institutions involved in the fight against corruption seems somewhat unlikely, but the experience of EU in this area can be partially passed on to others. Meanwhile, the regulatory and coping patterns of the EU and its member states can also be used for the Islamic Republic of Iran.
\end{abstract}

Keywords: corruption, Europe, anti-corruption monitoring group of countries, regulatory system of the group of states against corruption (GRECO)

\section{Introduction}

The concept of corruption has been changed in the current situation, influenced by the conditions of globalization, and the tools to combat have been also changed. Scholars believe that corruption has been used in different meanings. In the Merriam-Webster dictionary, corruption is defined as illicit reward to force a person to disobey the task ${ }^{1}$. According to the definition of the World Bank, corruption is the abuse of state power for personal benefits ${ }^{2}$, and it is clear that abusing state power is not always for personal benefit, but also in the interests of a particular political party or class, friends, family, etc. ${ }^{3}$ The definition of "Transparency International" ${ }^{4}$ is different from the World Bank definition. This institute defines corruption as the abuse of

\footnotetext{
1 "Corruption." Merriam-Webster.com. Merriam-Webster, 2015.

${ }^{2}$ http://www1.worldbank.org/publicsector/anticorrupt/corruptn/cor02.htm Web. 21 Jul 2015.

${ }^{3}$ World Bank, 1998, table 1, pp. 190-191.

${ }^{4}$ Transparency International was founded in 1993 as a non-profit and non-governmental institution in Germany. It is headquartered in Berlin and has 100 branches worldwide. From 1995, the organization started to rank countries in terms of corruption and publication of Corruption Perception Index (CPI) in order to encourage governments to adopt anti-corruption policies. In addition to the World Bank index, it is one of the international references referred to assess the financial and administrative corruption.
} 
public position for private benefit ${ }^{5}$.

According to Gray Becker, winner of the Nobel Prize; if we remove the government, corruption will be removed. From the perspective of "Becker", a large share of corruption in the country is related to the government or occurs in it, although there is corruption in the private sector. Gray and Kaufmann have been defined corruption "the exploitation of public office for the private gain". ${ }^{6}$ Gunnar Myrdal looks at corruption in the broader sense defines all forms of deviation or personal power imposition and illegal exploitation of the job as corruption.

Corruption is considered as one of the main causes of backwardness and underdevelopment of countries and this gives much more importance to fight it, and made governments to deal with corruption using the necessary tools and the experiences of other countries. Thus, sensitivity and attention of national and international societies to the issue of corruption have been growing. Experts and policy makers of economic social and legal affairs concluded that corruption has become a global and comprehensive phenomenon and is broadly visible in all developed and developing countries in different sectors both public and private. Nowadays, governments are not necessarily involved in corruption but also community and other segments of society are dealing with corruption. Increasing public confidence and improving the welfare of society are the priorities; with this interpretation, the fight against corruption is intended to improve the welfare and development of society.

Fisman introduces the relation between corruption, crime, violence, and poverty a problem of "chicken and egg" where the root cause is not clear. He describes the complexity of the issue as: "When bribes paid in tax returns are not reflected, they are not shown in annual reports or, cash flows, so we face the problem of "chicken and egg" that we cannot even properly see chickens and eggs.",

Until recently, developed countries such as Germany, the Netherlands and Switzerland - the countries who are very strict in dealing with corruption within their borders, and other developed countries, not only permit paying bribes to foreign officials, but also consider such payments as business payments and therefore, consider them with tax breaks. On the one hand, this led private companies to annually register huge sums in their offices as bribes to pay less tax, and on the other hand, broadened the borders of corruption far beyond the country's borders.

The complexity of relationships and breadth of communication and prevalent of corruption are such that there is no choice for governments but to engage in the fight against corruption. The results of the phenomenon of corruption have changed and there is growing complexity in combating it. Globalization of corruption phenomenon has led countries to the seriousness and the need to combat it on a global scale. In the twenty-first century, governments have adopted development policies, and governments' international engagement is going more rapidly. Adoption of these policies has made corruption effective in relations between countries, and governments are faced with new crises. The penetration of the phenomenon of corruption into the country, has found external source, and new factors outside the borders, exposed countries to new challenges from within. That is why it is essential to adopt new mechanisms to deal with corruption. From a modern perspective, international and regional institutions play a fundamental role in promoting and facilitating the global cooperation. In the context of regional and international institutions and regimes, the possibility of implementing different strategies is provided. Regional international institutions are as the known behavior patterns of acts around which the expectations of the actors converge and get closer together. In this way, international and regional institutions and mechanisms that have been defined for them will be mostly focused by governments; and they will become important by recognizing them as new actors who are trying to help the government in the fight against corruption. Mechanisms are defined commensurate with the evolution of corruption and its spread to areas outside the borders of countries for tools and international institutions in combating corruption, such as the United Nations Convention Against Corruption (UNCAC) ${ }^{8}$ and the International Association of Anti-Corruption Authorities (IAACA), etc. Accordingly, international institutions, communication channels and governments increased interactions have arisen for this matter. Increasing the interactions of governments, presenting the common knowledge and experiences and increasing the inter-subjectivity agreement between actors, these institutions promote the spirit of cooperation and coordination between countries to combat corruption, and open a new window against corruption. In addition to governments as major actors in the world today, other actors have also emerged that their role is growing every day.

\footnotetext{
${ }^{5}$ www.transparency.org

${ }^{6}$ Gray, Cheryl W, and Daniel Kaufmann, 1998.

${ }^{7}$ Raymond Fisman, Edward Miguel - p. 33

${ }^{8}$ https://www.unodc.org/unodc/en/treaties/CAC/
} 


\section{First Speech: Historical Evolution Process of Combating Corruption}

Historically, growing concerns about corruption spread as an international problem in the 80 s and 90 s and documents and reports were developed in response to these concerns, which were:

- Legally binding documents which set out certain provisions or criteria that have legal binding nature and member states are obliged to act within the framework of international law;

- Imperative legal documents which set out criteria with a legal nature, but without legal requirements;

- Imperative documents which set out criteria with illegal nature, such as the allocation of resources to fight corruption;

- Other documents, for example, may contain political commitments, the obligation to formulate documents or other measures against corruption and similar issues, ${ }^{9}$

EUA has twenty-eight member states and a long-term continuous and comprehensive fight against corruption and impressive successes have been achieved. Economic, legal and political strategies of the Union and the cooperation between the monetary and financial institutions (particularly the ECB), economic and judicial cooperation of member states today, suggest a relatively successful face of EU in the process of combating corruption.

The Union began working with the moderate anti-corruption instruments in 1995, which mostly targeted the deviation of investment in EU. ${ }^{10}$ However, EU spread its focus over the years.

In 1995, Council of Europe adopted the Convention on the Protection of the material interests of the European Communities (EU Convention). ${ }^{11}$ EU Convention covers the embezzlement of union funds through fraud and documenting. A year later, in 1996, a protocol was included in the Convention. ${ }^{12}$ This protocol includes coordinated definitions and penalties prescribed for corruptive offenses. In 1997, the convention on the fight against corruption including agencies of member states was adopted. ${ }^{13}$ On 22 July 2003, the Council of Europe adopted the Decision Framework 2003/568/JHA on combating corruption in the private sector $^{14}$, which covers the profit and nonprofit business activities (except cases such as activities of NGOs, sports clubs, etc.).

In a decision in October $2008^{15}$, the Council adopted a network of contact points between member states to increase cooperation between the authorities in combating corruption in Europe. Furthermore, the Stockholm program offers a roadmap for the Union in the period of 2010 to 2014 in the field of justice, freedom and security; and corruption is determined as one of the objectives of the program. ${ }^{16}$

However, the EU recognized that its anti-corruption instruments act scattered from each other, and success can be closer by providing a coherent policy against corruption in all spheres of activity. In addition, the reports that indicated corruption has been increased in countries that have joined the EU recently, reinforced the view that EU must include anti-corruption requirements in the membership negotiations. ${ }^{17}$ Moreover, the recent crisis in the euro zone indicates the fact that differences in moral of nations and their way of governance can endanger the Union institutions. These considerations led the Union to establish a comprehensive anti-corruption framework.

In 2011, the Commission adopted a proposal for the harmonization of prevention laws, including protective orders on corruption. ${ }^{18}$ In June 2011, the Commission published a correspondence with the Parliament of

\footnotetext{
9 Peter Langseth et al, p. 587

${ }^{10}$ Centre d'etude pour l'application du droit communautaire en matière pénale et financière , 1998.

11 Council Act drawing up the Convention, p. 48-57.

12 Which came into force on October 17, 2002.

${ }^{13}$ Council Act of 26 May 1997 drawing up the Convention made on the basis of Article K.3 (2)(c) of the Treaty on European Union, , p. 2-11.

14 Council Framework Decision 2003/568/JHA of 22 July 2003 p. 54-56.

15 Council Decision 2008/852/JHA of 24 October 2008, p. 38-39.

16 The Stockholm Programme - An open and secure Europe serving and protecting citizens," O.J. C 115,

${ }^{17}$ Transparency International, “ oney, Politics, Power: Corruption ris s in Europe,” National Integrity Assessment report of 6 June $2012,3$.

18 Proposal for a Directive of the European Parliament and of the Council on public procurement, COM(2011) 896 final, 20 December 2011, Article 55. 1 (b). See also Proposal for a Regulation of the European Parliament and of the Council on the access of third-country goods and services to the Union's internal mar et in public procurement and procedures supporting negotiations on access of Union goods and services to the public procurement markets of third countries, 21 March 2012, $\operatorname{COM}(2012) 124$ final.
} 
Europe, which focused on strengthening the existing tools. ${ }^{19}$

In this correspondence, it was stated that there is an appropriate framework for the fight against corruption in Europe and international level, but the main challenge is to strengthen the existing instruments. This correspondence launched a new reporting on corruption mechanism in the Union. Since 2013, every two years, the EU has published a report with two objectives: first, pathology of the problems associated with corruption at EU level, then reporting the specific problems raised in each of the Member States on a country by country analysis. The report recommendations are not binding, but the realization of them will be discussed in later reports. The goal is the close cooperation with the group of the member states against corruption, GRECO, and also preventing parallel reporting mechanisms ${ }^{20}$. At the same time, the EU negotiates on the membership of GRECO members in the EU. Among other existing active measures is a legislative proposal for coordination in regulations of Asset Recovery in the EU.

\section{Second Speech: Explaining the Anti-Corruption Conventions in Europe}

\section{A. Convention on Combating Bribery of Foreign Public Officials in International Business Contracts}

In 1989, the Organization for Economic Cooperation and Development member countries included 29 members: Canada, United States, most European countries, Japan and South Korea. This treaty members including Argentina, Australia, Austria, Belgium, Brazil, Bulgaria, Canada, Chile, Czech Republic, Denmark, Finland, France, Germany, Greece, Hungary, Ireland, Iceland, Italy, Japan, Korea, Mexico, Netherlands, New Zealand, Norway, Poland, Portugal, Slovakia, Slovenia, Spain, Sweden, Switzerland, Turkey, Great Britain and the United States, began to work in order to conclude a treaty that guaranteed the fight against corruption and bribery in international transactions. At first, The Council of Ministers of the Organization adopted non-binding recommendations on bribery and communicated them to members to be considered by members in international commercial transactions. Finally, the treaty was signed with the participation of five non-member countries, including Argentina, Brazil, Bulgaria, Chile and Slovenia in Paris on 17 December 1997 and came into force on February 15, 1999. The main objective of the Convention was combating bribery in international business transactions and contracts. This treaty is known as OECD convention. ${ }^{21}$

\section{Convention Overview}

OECD convention is a framework for criminalizing corruption in international commercial contracts, where the "active corruption" or "active bribery" (briber) means a person who attempts to commit a crime by promising or bribing, and the "passive bribery" (bribee) is the crime committed by the person who is bribed. However, the Convention does not use the term "active bribery" to avoid misconception about the initiative of the briber and considering the bribee as a passive victim. In fact, in a number of successes, the bribe receiver takes steps to encourage or put pressure on the briber and will have a more active role.

The above convention obliges each of the member countries to adopt measures to consider proposals, promises or giving any unjustified money, or additional advantage to a foreign public official in order to conduct or omission of an action in connection with his duties for obtaining improper business advantages in the field of international trade as a criminal offense in law. ${ }^{22}$

Punishment of persons charged with bribing foreign public officials, including officials of countries that are not party to the Convention in order to obtain or retain international business, is obligatory. Acts of complicity in the crimes, including incitement, aiding and abetting or permitting bribing a foreign official will be considered a criminal offense. ${ }^{23}$

Punishments include appropriate, acceptable and criminal punishments similar to punishments applicable to bribery of domestic public officials, including imprisonment, bribery or the proceeds of the bribery of a foreign public official or property with the same price, in subject to confiscation or applying applicable monetary penalties. ${ }^{24}$ Of course this Convention, merely sought to ensure the criminalization by countries to punish

\footnotetext{
${ }^{19}$ Communication from the Commission to the European Parliament, the Council and the European Economic and Social Committee, Fighting Corruption in the EU, 6 June 2011, COM(2011) 308 final.

20 "Commission steps up efforts to forge a comprehensive anti-corruption policy at EU level," E O 11/376, press release of 6 June 2011.

${ }^{21}$ Organization for Economic Co-operation and Development

${ }^{22}$ Article 1, paragraph 1 of the OECD Convention

${ }^{23}$ OECD Convention with "America FCP law" is different from this perspective that the above treaty does not consider the illicit gifts and payments to foreign political parties and candidates and it is unclear whether the Convention is reliable for the Bribery of Foreign Public Officials' family members or not.

${ }^{24}$ Article 3, paragraph 3 of the Treaty OECD
} 
bribery of foreign public officials, without the requirement of integrity or changes in the basic principles of the legal system countries (Article 1 [1]). Although the definition of bribery in this Convention does not covers bribery of a foreign political party or candidates of a foreign office. This Convention recognizes the responsibility of companies that bribe or benefit from paying bribes ${ }^{25}$. However, the Convention does not set out criminal liability in this regard. Companies are merely exposed to effective proportionate and justified non-criminal penalties including financial penalties. It was also noted that the Convention does not set out any integrated punishment for any natural or legal person in exchange for bribes. The Convention also ensures that bribes paid to foreign public officials, similar to bribes paid to national authorities, are covered by the provisions of offense regulations ${ }^{26}$. In addition, in order to avoid the deviation of huge amount of company accounts in order to pay bribes, the Convention strengthens preventive actions based on the accounting requirements. The Convention also calls for urgent and effective legal assistance for criminal and non-criminal investigation ${ }^{27}$ and points out that the principle of "banking secrecy" cannot be used in order to evade such assistance. However, the Convention has no paragraph about demand and reporting based on the presence of corruption.

The Convention is not self-executing and hence the penal provisions must be developed again in Member States. The Convention is open for acceptance by any country that is a full member of OECD working group on bribery in international commercial contracts and is able to adopt its requirements ${ }^{28}$. Nations willing become a member of the Convention, must acquire the permission to participate in the OECD Working Group. The members of this working group are also committed to the requirements listed in the modified version of recommendations related to the combat against bribery in international commercial contracts. Moreover, they have to participate in the supervisory mechanism under the auspices of the working group for bribery.

One of the main tasks of the OECD working group on bribery is organizing ongoing investigations on implementation of the Convention in countries. The process relies on self-assessment and mutual assessment. These systems obey certain principles that are applied across OECD member countries to guarantee commitments by countries.

Investigations above consist of two stages: In the first stage which started in 1999, executive regulations of each signatory country are evaluated to ensure compliance with the standards set by the Convention. In the second stage which began in 2001, the group reviews the structure formed to implement rules and regulations of the Convention and estimate their practical actions.

B. EU Convention on the combat against corruption involving officials of the European Communities or officials of Member States, 1998

In 1998, a draft convention was proposed in order to ensure that not only fraud against the financial interests of the communities, but also all corrupt acts taken place with the participation of officials of the European Communities or officials of member states face criminal prosecution.

After the above-mentioned initiative, on May 26 1997, the Council approved the law drawing the treaty on the combat against corruption involving officials of the European Communities or officials of EU member states. ${ }^{29}$

This treaty only considers the actions taken by the EU authorities and the member states. Measures of this Convention necessarily include bribery and similar charges that the Member States should prosecute by the criminal code. This Convention does not consider affairs such as fraud, money laundering and other corruption-related measures. Therefore, based on this Convention, the definition of "authority" includes different categories of persons (including national authorities of other Member States) in order to secure the highest and most consistent possible coverage of basic provisions of the Convention on the combat against corruption. ${ }^{30}$ "Community authorities" mean not only permanent authorities under staff rules of the European Communities' authorities, but also include different categories of other contract staff included in the terms of employment. However, members of social institutions, Commission, European Parliament, Court of Justice of the European Communities and the European Court of Auditors, are not covered by this definition, but they are mentioned in

\footnotetext{
${ }^{25}$ OECD, Article 2

${ }^{26}$ OECD, Article 7

${ }^{27}$ OECD, Article 9

${ }^{28}$ OECD, Article 13

${ }^{29}$ OJC195,25.6.1997, p. 1

${ }^{30}$ Article 1, the EU Convention on the combat against corruption involving officials of the European Communities or officials of Member States, 1998 (EU Treaty)
} 


\section{Article 4 of the Convention. ${ }^{31}$}

"National Authority" means an authority or government official in accordance with the definition given in the national legislation of each Member State to be used in their criminal law. Here the concept of "public official" automatically does not include members of parliament, ministers, members of the Supreme Court or the Court of Auditors in the Member States. However, this does not prevent the expansion of the definition of National Authority to one or more categories of the above-mentioned persons by Member States. ${ }^{32}$

The Convention considers the request-based passive corruption, agreement or receiving certain things, either directly or through intermediaries as crimes, that can include:

1. A one-sided performance by an official to bribe for an act done or not done, the person who is looking for his own interest; here, paying or not paying the bribe is unimportant and the bribe request is the basis of the above charges;

2. Accepting or receiving specific things by the accused person following the mutual understanding of the bribe between the recipient and payer; the above charge is completed when the agreed items are exchanged, even if subsequently, the authority withdraws the agreement, or returns the special thing. ${ }^{33}$

Convention does not distinguish between direct and indirect means of corruption. The fact that an intermediary may be involved in crime that would extend the scope of passive corruption to the inclusion of the indirect action of the authority, necessarily entails identifying the criminal nature of the act, regardless of good or bad will of the mediator involved. This charge also covers cases in which an official is asked for e.g. a gift or other advantage to a third party as a colleague or partner, a close friend, a political party or other entity. The article also covers situations in which the internal law of specific countries covers items in which an official receives advantages contrary to his official duties, based on his fair performance for example, accelerating or suspending the investigation process of a file.

Similarly, the Convention also counts active corruption a crime. Article 3 states that any deliberate action of anyone to promise or provide an advantage to an "official" will be held within the scope of this article. The corrupt person can be a private individual or representative of a company or a person with a governmental task. Action of the corrupt person can include a promise or offer, directly or through an intermediary, of an object or a kind of intangible advantage, regardless of whether the request is acted or not and the advantage becomes objective or not ${ }^{34}$. However, the underlying act of corruption must be done consciously, as a deliberate tendency for taking action by an official who is contrary to the duties assigned to the position.

Article 5 obliges Member States to ensure that active and passive corruption offenses as well as participation or incitement of the offense will be punished by criminal sentences. Penalties should be effective, proportionate and acceptable. As the Court of Justice of the European Communities argues:

"Member states should especially ensure that violations of European Community law, administrative and constitutional form, will be punished under the same conditions applied against violations of national laws with a similar nature and importance. And in any case, the penalties must be effective, proportionate and acceptable."35

Similar to criminal responsibility in the case of active corruption, Article 6 allows Member States to count senior managers and decision-makers of huge business companies criminally responsible. In the sense of Article 6, a Member State can consider the heads of business companies and major decision-makers criminally responsible, if negligence is occurred towards a regulatory or control duty. However, the Convention gives considerable freedom of action on the basis of criminal liability of heads of businesses and major decision-makers of the Member States.

Article 8 considers extradition of criminals and criminal prosecution. Article 8 initially obliges the Member States that do not extradite individuals with their national citizenship to adopt the measures necessary to establish jurisdiction over the offenses covered in Articles 2, 3 and 4 of the Convention when they are conducted

\footnotetext{
${ }^{31}$ Article 4 is designed for broadening the range of anti-corruption standards set forth in the Treaty through the harmonization of criminal law of each Member State and complying with the specific allegations of persons with specific positions in the institutions of the European Community. As the first Protocol, a merging principle is raised, according to which the member states are obliged to apply definitions of similar corruption allegations for members of European society organizations and individuals with similar positions in their own domestic institutions.

32 Article 4, (2) and (3,) EU Treaty

33 Article 2, EU Treaty

${ }^{34}$ Article 2/3, EU treaty

${ }^{35}$ In the judicial record (27) 88/68, September 21, 1989, ECR, 2965. See the Web page: http: //www.legaltext.ee/text/en/T70106.htm
} 
by people in their national citizenship in other member states. In addition, if a corrupt action occurs in the territory of a Member State by a person with the nationality of another Member State, and he cannot be extradited simply because that Member State does not extradite its own nationals, Article 8 obliges the Member State to provide records requested by the legal authorities for criminal prosecution. Thus, Article 8 (2) clearly establishes the principle "aut dedere aut judicare".

In order to apply this principle, the requesting Member State is obliged to transfer records, information and documents related to the crime to that member state so that the person can be criminally prosecuted. The requesting Member State will be in the process of criminal prosecution and the results.

Various forms of cooperation between the member states are listed in Article 9 as follows: Mutual legal assistance in criminal matters, extradition of criminals, transfer of proceedings and enforcement of judgments issued in other Member States, allowing the use of the most appropriate means of cooperation in each specific case. If more than one member state has jurisdiction to criminally pursue the crime, the above article obliges Member States to cooperate in decision-making about the country with the most jurisdiction for criminal prosecution. $^{36}$

The above article sets out the principle of "ne bis in idem" or a ban on parallel proceedings, which means that no one should be punished twice for the same crime ${ }^{37}$. The above principle is very important in international corruption cases in which several courts have jurisdiction and it is impossible to centralize the criminal prosecution in a single country. The above article also notes that the periods of imprisonment in a different Member State, must be taken into account in all cases by country that has begun another criminal prosecution.

\section{Third speech: Proceedings of the Council of Europe}

On 6 November 1997, Committee of Ministers of the Council of Europe ${ }^{38}$ approved Resolution 24 on the twenty guiding principles to combat corruption. The resolution above arose from the "anti-corruption action plan" drafted by the Multidisciplinary Group against Corruption (GMC) $)^{39}$. This Action Plan investigated the nature and causes of corruption and provided the work program which included reviewing and providing recommendations in various fields such as criminal law, administrative law, tax aspects, civil rights, institutions and groups with specific duties and responsibilities related to corruption, prevention, investigation, punishment of corruption, etc. The Committee of Ministers obliged GMC to create international tools to give effect to the Action Plan and its implementation before December $2000^{40}$. In May 1998, the Committee of Ministers formed the "Group of States against Corruption» (GRECO) that would monitor the implementation of the Convention and appliance 20 guiding principles set.

In November 1998, the Committee of Ministers of the Council of Europe approved the Criminal Law Convention text, and the Convention on civil laws related to corruption in November 1999.

\section{Criminal Law Convention ${ }^{41}$}

In the nineteenth conference on "Valletta" that was held in 1994, Justice Ministers of the Council of Europe stated that corruption is a serious threat to democracy, the rule of law and human rights; it also advised the Committee of Ministers to form a multidisciplinary team on corruption under the responsibility of the criminal-related Committee (CDPC) and the Committee on Legal Cooperation (CDCJ) whose duty is to determine the appropriate measures for inclusion in an operating program at the international level and examine the possibility of drafting legal or executive laws (including international conventions) in this regard.

Accordingly, the Committee of Ministers formed a multidisciplinary team related to corruption (GMC) in

\footnotetext{
${ }^{36}$ Article 2/9, EU Treaty

${ }^{37}$ Article 10, EU Treaty

${ }^{38}$ COE members are as follows: Albania, Andorra, Armenia, Austria, Azerbaijan, Belgium, Bulgaria, Croatia, Cyprus, Czech Republic, Denmark, Estonia, Finland, France, Georgia, Germany, Greece, Hungary, Iceland, Ireland, Italy, Latvia, Liechtenstein, Lithuania, Luxembourg, Malta, Moldova, Netherlands, Norway, Poland, Portugal, Romania, Russia, San Marino, Slovakia, Slovenia, Spain, Sweden, Switzerland, the former Yugoslavia, Turkey, Ukraine and Britain.

${ }^{39}$ GMC argues that "corruption is the worst and yet most common form of behavior from antiquity to the present; it will be detrimental to the implementation of government affairs when it is neglected by government officials and MPs. In recent centuries, the above issue also involved the scope of the private sector."

40 "Donald Piragov", "international anti-corruption initiatives" in "efficient management of criminal justice to prevent corrupt activities by public officials," the agenda of the one hundred and thirteenth International Training Course, Part II, reference data set, No. 5, UNAFEI, 2000 .

${ }^{41} \mathrm{http}: / /$ conventions.coe.int/Treaty/EN/Treaties/Html/173.htm
} 
September 1994, and transferred the duty to review the appropriate measures for inclusion in an international operating action plan against corruption to the group.

GMC began its work in May 1995 and provided a draft of action plan against corruption which was presented to the Committee of Ministers in January 1996 and finally was approved in November 1996 and its implementation was put in charge of the GMC before December 31, 2000. GMC jurisdiction is as follows.

- Under the responsibility of the European Committee on crime-related issues (CDPC) and European Committee on Legal Cooperation

- Immediate development of one or several international conventions against corruption, and a follow-up mechanism to implement the requirements of the treaties or any other legal instrument in this field

- Immediate development of draft of a European administrative law for public officials

- After consultation with the relevant organizing committees, starting organizing or strengthening the research projects, educational programs and national and international exchange of practical experiences related to corruption and combat against it

- Implementation of other parts of the Anti-Corruption Action Plan, taking into account the priorities set out

- Considering the performance of the other boards and international organizations in view of ensuring a coherent and coordinated approach

- Consultations with CDCJ or CDPC on any draft legal text relating to corruption and considering the views of them

On November 6, 1997, the Committee of Ministers of the Council of Europe approved 20 strategic principles to combat corruption at the hundred-first session. Ministers have agreed on the following issues with firm believe in the synchronization process of anti-corruption measures in their countries:

- Ensuring coordinated national and international corruption criminal prosecution (Article 2)

- Ensuring that persons responsible for the prevention, investigation, criminal prosecution and adjudication of charges on corruption, have the independence and autonomy appropriate to their tasks and are not put under improper influence; and have means needed for gathering evidence, protecting the persons who help the authorities in combating corruption, and protecting the confidentiality of the investigation (Article 3)

- Providing appropriate standards for detention and obstruction of proceeds from corruption offenses (Article 4)

- Preventing the use of legal persons as a shield against charges of corruption (Article 5)

- Strengthening the expertise of persons or bodies responsible for combating corruption and providing proper tools and training to carry out their duties (Article 7)

- Developing international cooperation at the highest level possible in all areas of the combat against corruption (Article 20)

In addition, the Committee of Ministers obliged GMC to immediately draw up an international legal instrument, following the Action Plan to combat corruption and draft an appropriate and efficient mechanism for monitoring compliance with the above guiding principles and implementation of adoptable international legal instruments. At its one hundred and second session in 1998, the Committee of Ministers approved Resolution 7 (98) based on the formation of "Group of States against Corruption GRECO» in the form of a limited agreement. In this resolution, the Committee of Ministers invited the Council of Europe member states and non-member states to participate in drafting of an agreement on their willingness to join the GRECO and notifying the Secretary-General. GRECO-related agreement and its rules were approved on May 5, 1998. GRECO is a board that is tasked with monitoring the compliance with the guiding principles in the combat against corruption, and implementation of international legal instruments pursuant to the Anti-Corruption Action Plan, through a process of mutual evaluation and overall review. GRECO full membership will be given to countries that participated fully in the process of mutual evaluation and agreed with their performance assessment.

Working Group on Criminal Law GMC began its work in February 1996 on a draft criminal law convention. In the period from February 1996 to November 1997, GMCP held 10 meeting, and finished reading of the draft convention twice. In November 1997, the working group transferred the above text to GMC for consideration. GMC began reviewing the draft at its eleventh plenary session in November 1997, and in February 1998, 
consulted with CDPC on the first cited version of the draft convention.

In September 1998, GMC agreed the final draft and presented it to the Committee of Ministers. On November 4, 1998, the Committee of Ministers approved the convention and started the process of signing it. The treaty above was the third Multilateral Convention against Corruption adopted, and its details were discussed among the member states of the Council of Europe.

The process of signing of the Convention was begun in January 27, 1998 in Strasbourg. Signing of the Convention is free for all members of the Council of Europe and five non-member countries (Belarus, Canada, Holy See, Japan, Mexico and America). Also, the European Union and other countries can be invited. The Convention came into force at the beginning of July 2002 and the signatories were 42 Member States and 3 non-member states. Until August 13, 2004, 30 countries have ratified the Convention. The Convention requires the adoption of new internal rules for estimating its requirements.

The main objective of the Convention on criminal law is establishing common standards in connection with specific charges on corruption, in spite of the fact that it does not provide a unified definition of corruption. In addition, the Convention considers the basic legal and administrative issues that are completely linked with the corrupt charges and want to strengthen international cooperation. Work on the convention began on the basis of the preliminary definition below: "Corruption from the perspective of GMC of the Council of Europe is: Bribery and any other behavior in relation to persons with responsibility in the public or private sector who violate their duties as public officials, private employees, independent brokers or other related positions, and the violation above is to obtain unjustified benefits of any kind for themselves or for others."

The Convention is divided into four chapters and 42 articles. It has an ambitious text with a broad scope of legal effect which has appreciable impact on the combat against this phenomenon in Europe. The convention includes corruption in both the public and private sectors. Corrupt practices involve a wide range of charges, including:

- Active and passive bribery by domestic and foreign authorities ${ }^{42}$

- Active and passive bribery of domestic and foreign representatives and members of international and transnational organizations that one of the Convention member states is of its members ${ }^{43}$

- Active and passive bribery by members of international civil society ${ }^{44}$

- Active and passive bribery in the private sector ${ }^{45}$

- Active and passive bribery of domestic, foreign and international judges and officials of international courts $^{46}$

- Influence trade ${ }^{47}$

- Money laundering ${ }^{48}$

- Accounting crimes ${ }^{49}$

Measures necessary for the implementation of the Convention include: criminal prosecution of accusations, regional cooperation and implementation of provisions related to asset recovery; members are required to ensure that there is a collective responsibility in connection with the criminal offenses of active bribery, trading influence and money laundering, where the crime is committed by a natural individual having a management position for the benefit of a legal person. Also, when a lack of supervision or control by a natural person who has a management position in a legal person leads to commitment of a criminal offense for the benefit of the legal person, the legal person will be in charge. Member States are required to ensure that criminal acts will face efficient, proportionate and acceptable measures and penalties. Users also have to seize or freeze the tools and proceeds from criminal activities, or assets in proportion to the revenue value. Member States should provide special investigative techniques to gather evidence and identification, and prosecute, arrest and obstruct the

\footnotetext{
${ }^{42}$ Articles 2, 3 and 5 of the Criminal Law Convention

${ }_{43}$ Articles 4, 6 and 10 of the Criminal Law Treaty

${ }^{44}$ Article 3 of the Criminal Law Treaty

${ }^{45}$ Articles 7 and 8 of the Criminal Law Treaty

${ }^{46}$ Article 11 of the Criminal Law Treaty

${ }^{47}$ Article 12 of the Criminal Law Treaty

${ }^{48}$ Article 13 of the Criminal Law Treaty

49 Article 14 of the Criminal Law Treaty
} 
revenue tools. ${ }^{50}$

Regulatory mechanism (GRECO) is considered in Article 24. The purpose of the mechanism is to monitor the actions of states in the combat against corruption, through mutual assessment process and pressure on member states to comply with the provisions of the Convention. One of the limitations of Convention obligations is that it has provided a certain number of considerations. It was felt that taking into account the possible considerations is necessary in order for the members to have a gradual adaptation to the requirements of this Convention. Other limitations include: few number of preventive measures and lack of preparation on laws related to limitations.

\section{Additional Protocol to the Convention on corruption-related criminal law}

On 15 May 2003, the Council of Europe added an Additional Protocol to the Convention on corruption-related criminal law $^{51}$, in order to complete the convention ${ }^{52}$ and provided the feasibility of a broader anti-corruption action plan 1996 (PCA). Working Group on Criminal Law (GMCP), as a result of issues related to draft an Additional Protocol to the Convention on criminal law, agreed to insert the issue of arbitration to this Convention.

Active bribery of domestic judges, passive bribery of domestic judges ${ }^{53}$, bribery of foreign judges, bribery of domestic jurors; bribery of foreign jurors, such as the Convention on corruption-related criminal law, will be monitored by the "Group of States against corruption» (GRECO). (Article 7)

\section{Civil Law Convention on the combat against corruption ${ }^{54}$}

It should be noted that the Committee of Ministers of the Council of Europe, on the one hundred and first session on November 6, 1997, approved Resolution (97) 24 on 20 guiding principles for the combat against corruption. Article 17 specifically points out that countries should "ensure that civil laws need to consider the combat against corruption and especially offer appropriate remedies for persons whose rights and interests are damaged through corruption."

In the twenty second conference in June 1999 in Chisinau, European justice ministers approved Resolution No. 3 on the combat against corruption, and asked the Committee of Ministers to approve the draft Convention on the Civil Aspects of corruption in such a way that the process of signing it begin before the end of 1999. Pursuant to the adoption of Criminal Law Convention on Corruption and resolutions (98) 7 and (99) 5 which implies the formation and implementation of the "Group of States against corruption» (GRECO), Council of Europe finalized an international legal instrument to combat corruption through civil law-based solutions.

As the Anti-Corruption Action Plan points out, in the combat against corruption, "the rules of law are directly linked to criminal and enforcement law. If a crime such as corruption is prohibited under criminal law, a petition for compensation can be made on the basis of committing a criminal act. Victims may find protecting their interests under civil law easier than using criminal law. Similarly, if an executive officer does not perform his duties and responsibilities properly, a petition for compensation can be presented."

GMC working group on civil law completed the draft civil law convention on corruption in 1998 that was presented to the GMC plenary session. GMC examined this text, and after approving it on June 24, 1999, transferred it to the Committee of Ministers, and the Committee ratified it in 1999.55

The purpose of the Convention on civil law is to oblige each member to predict effective solutions in their domestic laws, for persons damaged by corruption, to enable them to defend the rights and interests, including through compensation. The Convention which is divided into three chapters (measures adopted on a national level, international cooperation and monitoring, and final paragraphs) is not self-executing. This means that the member states will insert the principles and rules contained in the Convention into their domestic law by considering their particular circumstances.

So, those Member States having laws already consistent with the provisions of this Convention or better condition in their domestic law, do not need to take additional measures. Ensuring the compliance of member states with the provisions of the Treaty of civil law will be done by the "Group of States against Corruption, GRECO» through monitoring activities in accordance with Article 14 of the Convention.

\footnotetext{
${ }^{50}$ Article 23 of the Criminal Law Treaty

${ }^{51}$ CETS no. 191

${ }^{52}$ CETS no. 173

${ }^{53}$ Article 3 of the Criminal Law Treaty

${ }^{54} \mathrm{http} / / /$ conventions.coe.int/Treaty/en/Treaties/Html/174.htm

${ }^{55}$ ETS no. 174
} 
The Convention which is the first attempt for perspiration of principles and common rules at the international in the field of civil law of combating corruption, deals with the issues of definition of corruption, compensation for damage, liability, affecting malpractice, periods of limitation, the validity of contracts, protection of personnel, accounting and auditing, collecting evidence, preparatory measures, international cooperation and monitoring.

\section{Conclusion}

With an overview of the standards and regulations in EU in the executive sector and the inspection system in member states known as GRECO, it is understood that the union has been trying to increase the thematic range and personal inclusion of provisions to combat corruption and strengthen GRECO's monitoring system in order to implement effective measures; and the success of the EU in this field is largely due to these measures. So that, according to reports and statistics compiled by Transparency International, it is known as the leader in the combat against corruption.

It should be noted that the EU achieved these successes by considering the appropriate social fields among member states and having national and international regulatory systems. Accordingly, generalization of the EU's pattern to other regional or global institutions involved in the combat against corruption seems so unlikely, but EU's experiences in this area can partially be passed on to others. In the meantime, the regulatory and coping patterns of the EU and its Member States can also be used for the Islamic Republic of Iran.

\section{References}

"Corruption." Merriam-Webster.com. Merriam-Webster, 2015. Web. 11 Sep 2015.

Centre d'etude pour l'application du droit communautaire en matière pénale et financière, Corruption de fonctionnaires et fraude Européenne, Bruylant, Bruxelles, 1998.

Commission steps up efforts to forge a comprehensive anti-corruption policy at EU level, E O 11/376, press release of 6 June 2011.

Communication from the Commission to the European Parliament, the Council and the European Economic and Social Committee, Fighting Corruption in the EU, 6 June 2011, COM (2011) 308 final.

Council Act drawing up the Convention on the protection of the European Communities' financial interests of 26 July 1995, O.J. C 316, 27 November 1995, p. 48-57.

Council Act of 26 May 1997 drawing up the Convention made on the basis of Article K.3 (2) (c) of the Treaty on European Union, on the fight against corruption involving officials of the European Communities or officials of Member States of the European Union, OJ C 195, 25 June 1997, p. 2-11.

Council Decision 2008/852 / JHA of 24 October 2008 on a Contact-Point Network against Corruption, O.J. L 301, 12 November 2008, p. 38-39.

Council Framework Decision 2003/568 / JHA of 22 July 2003 on combating corruption in the private sector, O.J. L 192, 31 July 2003, p. 54-56.

ETS, no $173 ; 174 ; 191$.

Fisman, R., \& Miguel, E. (n.d.). Economic criminals: corruption, violence and poverty of nations, translated by Farrokh Ghobadi, Negahe Moasser Publications, p. 33.

Gray, C. W., \& Kaufmann, D. (1998). "Corruption and development", in IMF / World Bank. Finance and Development, 35(1), 7.

http: //conventions.coe.int/Treaty/EN/Treaties/Html/173.htm

http: //www.legaltext.ee/text/en/T70106.htm

http: //www1.worldbank.org/publicsector/anticorrupt/corruptn/cor02.htm Web. 21 Jul 2015.

http://conventions.coe.int/Treaty/en/Treaties/Html/174.htm

https: //www.unodc.org/unodc/en/treaties/CAC/

Judicial file (27) 68.88, September 21, 1989, ECR, p. 2965.

Peter Langseth et al. (n.d.). the global anti-corruption program, translated by Amir Hossein Jalali Farahani and Hamid Bahremand Bak Nazar, Majlis Research Center, p. 587.

Piragoff, D. (2000). International anti-corruption initiatives in the efficient management of criminal justice to prevent corrupt activities by public officials, one hundred and thirteenth work program for International Training Course, Part II, reference data set, No. 5, UNAFEI. 
Proposal for a Directive of the European Parliament and of the Council on public procurement, COM (2011) 896 final, 20 December 2011, Article 55. 1 (b).

Proposal for a Directive of the European Parliament and of the Council on the freezing and confiscation of the proceeds of crime in the European Union, 12 March 2012, COM (2012) 85 final.

Proposal for a Regulation of the European Parliament and of the Council on the access of third-country goods and services to the Union's internal mar et in public procurement and procedures supporting negotiations on access of Union goods and services to the public procurement markets of third countries, 21 March 2012, COM (2012) 124 final.

The Stockholm Programme - An open and secure Europe serving and protecting citizens, O.J. C 115, 4 May 2010, p. 1-38.

Transparency International, oney, Politics, Power: Corruption ris s in Europe, National Integrity Assessment report of 6 June 2012, 3. The report refers in particular to the Czech Republic, Hungary and Slovakia.

World Bank. (1998). World Development Report 1998. New York, Oxford University Press. pp. 190-191.

www.transparency.org

\section{Copyrights}

Copyright for this article is retained by the author(s), with first publication rights granted to the journal.

This is an open-access article distributed under the terms and conditions of the Creative Commons Attribution license (http://creativecommons.org/licenses/by/3.0/). 